\title{
Erratum to: Comparative study of experimental foot-and-mouth disease in cattle (Bos indicus) and buffaloes (Bubalus bubalis)
}

\author{
Mohan S. Maddur • Mukund R. Gajendragad • \\ Susurla Gopalakrishna $•$ Nem Singh
}

Published online: 15 December 2009

(C) Springer Science + Business Media B.V. 2009

\section{Erratum to: Vet Res Commun (2008) 32:481-489 DOI 10.1007/s11259-008-9051-0}

The original version of this article unfortunately contained mistakes.

The name of the first author is incorrect. It should have been "Mohan S. Maddur" instead of "M. S. Mohan".

The scientific name of Indian buffalo should have been "Bubalus bubalis" instead of "Bubalis bubalus".

The online version of the original article can be found at http://dx.doi.org/10.1007/s11259-008-9051-0.

M. S. Maddur $\cdot$ S. Gopalakrishna

Indian Veterinary Research Institute, Bangalore 560024, Karnataka, India

M. R. Gajendragad $(\bowtie)$

Project Directorate on Animal Disease Monitoring and Surveillance, Hebbal, Bangalore 560024,

Karnataka, India

e-mail: gajendragad@gmail.com

N. Singh

Joint Directorate of Research, Indian Veterinary Research Institute, Izatnagar 234143, UP, India 